DOI $10.23859 / 2587-8352-2017-1-4-5$

UDC 94(47).083

\author{
Dmitry Aronov \\ Doctor of Historical Sciences, Associate Professor \\ Oryol State University \\ Oryol, Russia \\ aronovdv@mail.ru
}

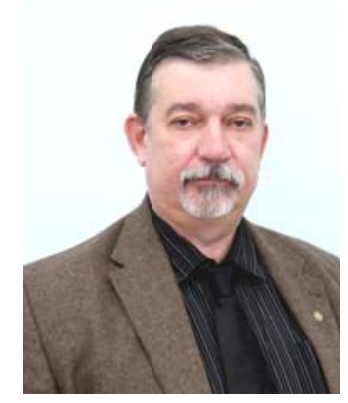

\title{
The post of President in the liberal projects of state structure in the Russian Democratic Republic in the early $20^{\text {th }}$ century
}

Abstract. This article explores the place and role of the institution of President in the liberal lawmaking in the early $20^{\text {th }}$ century, examines the results of a comparative study of the texts of liberal drafts of Constitution of Russia at the beginning of the $20^{\text {th }}$ century relating to this topic, as well as the law-making process of the Special Committee and the Minister of Justice in the Provisional Government. The author concludes that the liberal projects relating to the introduction and functioning of the institution of Acting (Provisional) President had a very insignificant effect on official lawmaking in 1917. Nevertheless, they are an exceptionally important source for characterizing the liberal lawmaking in the era of systemic social and political crisis. In author's opinion, the project of introducing the post of Provisional President in Russia confirms the general conclusion that the liberal recipes for overcoming systemic crises, based on supremacy of legal ways of transforming public life, do not work. In a revolutionary time, the choice of society tends toward other ways of reforming the social reality and seeks recipes for overcoming the social crises that offer simple solutions understandable to the broad masses.

Keywords: liberal lawmaking, liberal drafts of Russian Constitution, the post of president, lawmaking of the Provisional Government

\section{Introduction}

The Russian Revolution of 1917 caused radical changes in the social and political system of the former Russian Empire. The question of the type of state power, widely discussed in the liberal socio-political thought, passed from the field of theoretical search into the sphere of practical politics. This problem, unfortunately, does not apply to the popular stories of the historiography of Russian Revolution of 1917, and this is typical for both domestic and foreign research traditions. Russian historiography focused on the problems of formation of the state governed by the rule 
of law ${ }^{1}$, models of public restructuring of Russia proposed by various political forces $^{2}$, moving the legal topics to the background. Foreign historiography in general, is only slightly interested in the processes of constituting the new Russian statehood ${ }^{3}$. Consequently, the problem remains unexplored in the research field of modern history as well as historical-legal sciences.

\section{Main body}

The idea of introducing the post of president in Russia much earlier than in 1917, when the liberal legal thought and political practice moved to the stage of embodiment of their theoretical constructs, including in the sphere of state building. Even in the period 1908-11, which historians traditionally attribute to the time of the actual failure of historical power to conduct the policy of reforms, the idea that the new democratic Russia could be headed by president had a certain spread in the liberal environment. Thus, upon returning to political activism, the chairman of the First State Duma, S.A. Muromtsev, whilst meeting colleagues during his deputy activities and party work, constantly touched upon the topic of a possibility of his going into politics again. F.A. Golovin left very interesting memories of those meetings. During one of his private conversations with S.A. Muromtsev, which took place shortly before his death, he invited him to support with his authority one of the political groups that were at the time at the stage of formation. According to him, S.A. Muromtsev replied that "he decided to evade direct participation in any political group". . He further made it clear that this was due to his hopes "for a new revolutionary movement,

1 See: Medushevskii A.N. Dialogue with Time: Russian Constitutionalists of the Late $19^{\text {th }}$ and Early $20^{\text {th }}$ centuries. Moscow, 2010; Glushkova S.I. The Problem of the Legal Ideal in Russian Liberalism. Ekaterinburg, 2001; Zhukov V.N. Russian Philosophy of Law: The Natural Law School of the First Half of the $20^{\text {th }}$ Century. Moscow, 2001; Kornev V.N. The Liberal Concept of State and Law in Russia at the Beginning of the 20 $0^{\text {th }}$ Century (1905-1917). Belgorod, 2001 and others.

See: Models of Public Restructuring in Russia. The $20^{\text {th }}$ Century. Resp. Ed. V.V. Shelokhaev. Moscow, 2004; Shelokhaev V.V. The Liberal Model of the Reorganization of Russia. Moscow, 1996; Repnikov A.V. Conservative Concepts of the Reorganization of Russia. Moscow, 2007; Mamitova N.V. Liberal Concepts of the Constitutional State in Russia (end of $19^{\text {th }}-20^{\text {th }}$ centuries). Moscow, 2001 and others.

See: Power and Legitimacy - Challengers from Russia. L.; N.Y., 2012; Butler W. Russian Law. London; Oxford, 2009; Late Imperial Russia: Problems and Prospects. N.Y., 2005; The Russian Revolution and the Soviet State. 1917-1921. Documents. Selected and Edited by Mc Cauley. L., 1975; The Russian Provisional Government. 1917. Documents. Selected and edited by R.P. Browder and A.F. Kerensky. Stanford Univ. Press. Stanford, California, 1961. Vol. I-III; The Rise and Fall of Soviet Union. A Selected Bibliography of Sources in English. L., 1992.

Russian State Historical Archive (RSHA), F. 1625, Op. 1, D. 3, L. 28. 
for the possibility of creating a republic and for taking on the role of president of such a republic if this was the case" 5 .

In general, the term 'president' was widely used in the legal terminology of Russia in relation to those posts in the hierarchy of public administration, where its use showed their primacy in comparison to the others. Without entering into a detailed analysis of this problematics, let us limit our scope at the example of halfjokingly, half-serious constitutional studies of the very same S.A. Muromtsev, whilst he was still a student. In his student years, together with N.V. Muraviov, a play, which was called 'In 30 years' was written for the student theatre. Among its actors were N.V. Muraviov in the role of Russian president and S.A. Muromtsev as the president of the Russian parliament ${ }^{6}$. In real life, the positions they had occupied in the system of public administration in Russia were called differently, but that was a somewhat different, albeit quite curious, plot.

One can see the same very post of minister-president (in fact, that of prime minister) in the 'liberation' ('Parisian') liberal draft of Constitution of Russia', prepared by the so-called 'Liberation' group of lawyers (N.F. Anenskii, I.V. and V.M. Gesseny, P.I. Novgorodtsev, S.A. Kotliarevskii, I.I. Petrunkevich, G.I. Shreider). The term 'president' was used in this project for officials who headed the parliament. Thus, in Article 50 it was said that each of the chambers of the bicameral parliament "elects its president, vice-president and secretaries by closed casting of votes". Article 63, on the arrangement of the judiciary, provided that "if a minister is brought to justice by one or both chambers, he is tried by a special court chaired by the president of the supreme court, members of that court and representatives of the highest cassation court of the Empire." Thus, in the 'liberation' project, the term 'president' is used to denote the prevalence of any position in the current hierarchy, but does not mean the supreme person of the state. Similar provisions include the draft Basic Law prepared by the Kharkov Law Society based on the text of the 'liberation' project. $^{8}$

In other liberal projects of Constitution of Russia in the early $20^{\text {th }}$ century, there is also no trace of the institute of presidency as the highest official, they do not contain this term even in relation to other power structures. The reasons here are, of course, different. Thus, 'Muromtsev's' project was drafted with the calculation of possible incorporation into the imperial legislation and language, and in terms of terminology

\footnotetext{
5 RSHA, F. 1625, Op. 1, D. 3, L. 28; Antsiferov N.P. From the Thoughts of the Past: Memories. Moscow, 1992, p. 182.

6 School and Life. 8.11.1910. 1735-1746.

'Law' is a weekly legal newspaper. St Peterburg, 1905, no. 21, 29th of May. St Peterburg,

8 For more details see: Aronov D.V., Sheparneva A.I., Leonova I.A., Kosheleva S.V. Draft Basic Law of the Russian Empire by Kharkov Law Society - a place and role in the liberal constitutional lawmaking of the early $20^{\text {th }}$ century. History of State and Law, 2017, no. 1, pp. 60-64.
} 
was as close as possible to it, as S.A. Muromtsev himself said at one of the Zemsky congresses. Speaking in the debate on the Draft Basic Law at the All-Russian Zemsky Union of city officials in July 1904, he noted that his authors "tried to stick to the language of our legislation, of course, without resorting to exaggeration".

The Ekaterinoslav project is generally very fragmented, as is the 'Guchkovsky' 10 . As for the 'Herzenstein' project (the Moscow City Duma project), the authors did not elaborate on the problem of organization of the executive branch, limiting itself to a very brief section on the legislative power. The main difference between that project and the others was the elaboration of economic issues and problems of local selfgovernment $^{11}$. There was also no institution of president in the program of the Constitutional Democratic Party, which, due to certain disagreements over the future state structure of Russia, contained the formulation that "the constitutional structure of the Russian state is determined by the Basic Law". At the Second Congress of the Party, the paragraph on the state structure was formulated more clearly under the influence of the local party committees: "Russia must be a constitutional and parliamentary monarchy". This provision remained unchanged until March 1917, when at the Seventh Congress of the Constitutional Democratic Party, the formulation regarding introduction of a democratic republic in Russia was adopted. A similar situation existed concerning women's electoral rights and the structure of parliament. As a matter of fact, the institution of presidency already presupposed the rejection of monarchy, which, correspondingly, was not included into the program requirements of the Cadets at that time. Based on these circumstances, we can say that the position of S.A. Muromtsev as rendered by F.A. Golovin, looks far more than different than the general trends peculiar to the then liberal political and legal practice.

The year of 1917 was extremely difficult for all political forces in Russia, but the common thing was that they all acted within the framework of the emerging legal field, which was largely the result of their political creativity. The historical power was personified in the imperial family name, and the most important acts in this sphere were those that were associated with the rejection of the former Russian throne. The political forces that came to power in October 1917, for some time formally retained the institution of the Constituent Assembly, with the convocation and the election of deputies happening after the October events. Almost dramatically,

9 Liberal movement in Russia. 1902-1905. Moscow, 2001, p. 275.

10 See: Aronov D.V. 'Draft Constitution of the Russian Empire with sections: The state system, the rights of citizens, public education' - from the political and legal heritage of Alexander Ivanovich Guchkov. History of State and Law, 2014, no. 24, pp. 49-53.

See: Aronov D.V. Reform of local self-government in liberal projects of the basic law of Russia at the beginning of the $20^{\text {th }}$ century: The experience of comparative study. History of State and Law, 2014, no. 12, pp. 41-46. 
the legal field of the country was nullified, the formation of a new regulatory system began, based on radically different legal ideas and principles.

If we are talking about the activities of the Provisional Government and political forces in this area, whose representatives were mainly recruited into its membership, played the role of experts, etc., they were to some extent limited by the basic liberal principles giving the priority first and foremost to statutory regulation. Significant influence on the practice of transforming the liberal ideas, expressed in party programmatics, was provided by the realities of the current political situation. As we noted above, the party formulations such as the state structure of Russia and the new political system were very seriously adjusted. It was not without the influence of personal political ambitions though. In the field of our interest, we can talk about the presidential ambitions of M.V. Rodzianko of the post-February period. Radical politicians' political positions changed mirror-like. In this respect, a very vivid example was the reorientation of the extreme right, who sometimes spoke with greetings and support of a democratic republic in Russia. Thus, V.M. Purishkevich called "the best Russian people" "to raise above the sacred banner of civil freedom, freedom of the western model"12.

In practice, the Provisional Government in that current situation believed it expedient to pursue a consistent policy in the development of constitutional legislation. In September-October 1917, the procedure for drafting the Basic Laws of Russia was formalized. A special commission was created within the framework of the active Legal Meeting. It included many famous public and political figures, as well as 'stars' of national jurisprudence: A.A. Bogolepov, N.I. Lazarevskii, V.F. Deriuzhinskii, V.M. Gessen, A.I. Ivanovskii, A.E. and B.E. Nol'de, E.E. Pontovich, who mainly belonged to the Constitutional Democratic Party.

For a very short period of its work, the commission developed several projects, among which were the following materials: "Theses on the question of Upper Chamber", "On the Organization of the Provisional Executive Power under the Constituent Assembly", "Articles of the Basic Laws on Autonomy"13. "On Organization of Provisional Executive Power under the Constituent Assembly" was fundamentally important for understanding the position of liberal political forces on the issue of future state-political structure of the country under the conditions of a systemic social and political crisis.

In accordance with the text of its first article, "the exercise of executive power should be entrusted to the Provisional President of the Russian Republic". In the

12 Purishkevich 'We made this coup'. 'Gravediggers of the Russian Empire' The 100th anniversary of the revolution of 1917. Available at: http://ruskline.ru/history/2016/04/05/my_proizveli_etot_perevorot/ (Access date: 12.09.2017) p. 52 .

Bobrova G.S. The Formation of Russian Constitutionalism. (PhD) Dis. Moscow, 2017, 
future, the fate of this institute of state power was to be decided by the Constituent Assembly, which was supposed to give the right for re-election for up to one year (Article 4).

These norms created a legal mechanism for transferring power to the Constituent Assembly from the Provisional Government. They also opened the possibility for reelection of Minister-Chairman of the Provisional Government, already present in the new structure of state power, where they could take the post of President of the Russian Republic, introduced into the Basic Law. This scheme, according to representatives of liberal jurisprudence in the Special Commission, provided continuity in the management of Russia, gave the necessary stability and strength of the executive power, guaranteed further development of systemic constitutional reforms.

The project detailed the powers and conditions for functioning of the institution of President. Specificity consisted in their performance as the Provisional President and, as was said in the text of the draft, "under the supervision of the Constituent Assembly and with the assistance of the Council of Ministers enjoying the confidence of the Assembly" (Article 2). The set of rights of the Provisional President of the Russian Republic was significant to analyze the position of liberal jurisprudence. The President was entitled to "the right of legislative initiative" (Article 5), the "bills are submitted for consideration by the Constituent Assembly by the Council of Ministers" (Article 5) on behalf of the President, whilst the President would observe "the execution of laws and made orders necessary for this" (Article 8). The President was entitled to issue decrees "on the structure, composition and procedure of actions of representative institutions, except for the judiciary, requesting necessary loans from the Constituent Assembly" (Article 9). The President was also permitted "all affairs of government" (Article 10), led foreign policy, oversaw the armed forces (as the supreme commander in chief they belonged to "the supreme command over all armed forces" (articles 11-12)).

The analysis of the text of the bill suggests that when drafting the status of the Provisional President, the liberal drafts of the Basic Law of the early $20^{\text {th }}$ century country were taken as its basis. This tendency continues in the articles that gave the Provisional President the right to appoint and dismiss those who replaced the main posts in the structure of the state administration. First, we are referring to such positions as Chairman of the Council of Ministers and ministers. The list also includes those officials of "civil and military departments, who are appointed and dismissed by the supreme authority based on valid legal acts" (Article 13). The Provisional President was also delegated the right to preside over the meetings of the Council of Ministers. In his absence, this function was performed by Chairman of the Council of Ministers (Article 17). Similarly, to the monarch in the liberal projects of 
the Basic Law of Russia of the beginning of the last century ${ }^{14}$, the President of the Russian Republic was protected from external influence by several special legal institutions. The obligatory inquiries from active deputies of the Constituent Assembly could not be addressed to him, and the articles providing for his responsibility to the Constituent Assembly had a general character, devoid of any specificity and containing very inaccurate language. In fact, they were talking about the possibility of receiving oral or written explanations from the Provisional President by the Constituent Assembly (Article 6). The real responsibility for the results of managerial actions in the project was assigned to Chairman of the Council of Ministers and sectoral ministers (Article 19). They were also responsible to the Constituent Assembly "for the decrees and orders sealed by the President"" . In fact, this was the adaptation of the institution of counter-signature, which was repeatedly mentioned and elaborated in 1904-06 in the liberal constitutional projects ${ }^{16}$.

We believe that the options for the restoration of monarchy in Russia, considered by individual researchers, are rather speculative, since they are based on a known legist tradition. Similarly, one can also talk about the opinion that this scenario fits into the vision of state's typology suggested by the Cadets ${ }^{17}$, although one can also see the evolution from the opinion of expediency to preserve the constitutional monarchy in the first days of the revolution, transformed into the decision of the Seventh Congress on introducing into the program provisions for a democratic republic. However, that would be a typical course of events under the conditions of a revolutionary gradual breakdown, when there would be a constant search for removal of any kind of cognitive dissonance between the sense of justice (if one likes it, the eternal Russian "search for truth") and the existing legal order. The presence of this dissonance and its threat to the social system, and even more so for the state system, had been repeatedly described by the representatives of national jurisprudence and, in particular, by S.A. Muromtsev in the work 'Law and Justice', which became for him the theoretical basis for the search for a model (mechanism) to eliminate this contradiction $^{18}$.

After the collapse of the monarchical form of government in 1917, the question of typology of Russian statehood was submitted to the Seventh Congress of the Cadet

14 Aronov D.V. Imperial concept in liberal projects, the basic law of Russia in the early $20^{\text {th }}$ century. Imperial and Monarchic Component of Liberal Ideology. Muromtsev Readings, Oryol, 2014, pp. 122-130.

15 Levchuk S.V. Constitutional projects of the Provisional Government of Russia in the inter-revolutionary period of 1917. Law and Life, 1996, no. 10, pp. 155-156.

16 See: Aronov D.V. Status of the monarch in the liberal projects of the Basic Law of Russia at the beginning of the $20^{\text {th }}$ century. History of State and Law, 2013, no. 3, pp. 14-17.

Bobrova G.S. Decree. op., p. 54.

18 See: Aronov D.V. Law and justice in the creative heritage of Sergei Andreevich Muromtsev. Reform or revolution. Bulletin of Higher Education Institutions, 2012, no. 3, pp. 9-13. 
Party. The ideologist of the Cadets was a well-known liberal lawyer F.F. Kokoshkin - he was an active supporter of the thesis on including a provision on a democratic republic as a form of government in the Cadets' program. "The republic in our eyes cannot but be the most perfect form of government, for," he said, speaking at the congress, "this is a form of government in which our democratic principle - the rule of the will of the people - is carried out in its fullest and purest form" $" 19$. To implement the provisions on the actual rule of democratic principles, F.F. Kokoshkin noticed, "in the republic there should be a separation of power," the legislative power was to "belong wholly to the representative assembly" "20. F.F. Kokoshkin's arguments, relating to the perception of the general political situation in Russia gave a unanimous vote of 323 delegates on the issue of amending paragraph 13 (on the state structure of Russia) in the party program of the Cadets. The new version ran as follows: "Russia should be a democratic parliamentary republic" 21 . Accordingly, the thesis about the immanent adherence of the Cadets to the restoration of monarchy required serious argumentation at minimum. As a matter of fact, after the abdication of Nicholas II and Mikhail Alexandrovich, the theoretical possibility of restoration remained, but that variant, analyzed by liberal jurisprudence, depended on the position of the Constituent Assembly ${ }^{22}$. Restoration of monarchy in theory could be implemented by both inviting to the throne representatives of the Romanov dynasty or another dynasty. It was the restoration of the Romanov dynasty that was impossible for many legal reasons, such as absence of regency institute, etc.

\section{Conclusion}

Thus, the liberal projects of introduction and operation of the institute of Provisional President that we considered in the article, influenced the official lawmaking of 1917 even less than the liberal projects of the Basic Law of 1904-06 influenced the imperial legislation of 1905-07, although at that time, the influence was, strictly speaking, negligibly small ${ }^{23}$. At the same time, they are an exceptionally important source for characterization of the liberal lawmaking in the era of systematic socio-political crisis. From this perspective, it can be said that the project of introducing the post of Provisional President in Russia confirms the general conclusion that liberal recipes for overcoming systemic crises, based on supremacy of legal ways of transforming public life, do not work. At such times, the choice of the

19 Congresses and conferences of the Constitutional Democratic Party. 1905-1920 years.

Vol. 3. Book 1. Moscow, 2000, p. 373.

20 Ibid., p. 377.

21 Ibid., p. 400.

22 See: Aronov D.V., Kosheleva S.V. Typology of state power in Russia in FebruaryOctober 1917. History of State and Law, 2017, no. 19, pp. 13-17.

23 Aronov D.V. From Lazavka to the Tauride Palace. Sergei Andreevich Muromtsev - politician, scientist, teacher. Oryol, 2010, pp. 158-161. 
society tends to use other recipes to overcome the social crises, offering simple ways to reform the social reality, understandable for the broad masses.

A promising field of research in this case would be studies of comparative nature that will enable us to identify and trace the degree of interrelation and mutual influence of liberal lawmaking in the early $20^{\text {th }}$ century, the model of liberal transformation of the country and the activities of the Provisional Government, as well as theoretical legacy of the liberal jurisprudence of the second half of the $19^{\text {th }}$ early $20^{\text {th }}$ centuries, and, to a certain extent, the emigrant period, which the Russian liberalism left to us.

\section{References}

1. Antsiferov N.P. Iz dum o bylom: Vospominaniia [From the Thoughts of the Past: Memories.] Moscow, 1992. 511 p. (In Russian)

2. Aronov D.V. Ot Lazavki do Tavricheskogo dvortsa. Sergei Andreevich Muromtsev-politik, uchenyi, pedagog [From Lazavka to Tauride Palace. Sergei Andreevich Muromtsev - Politician, Scientist, Teacher] Oryol: Publisher Alexander Vorob'ev, 2010. 300 p. (In Russian)

3. Aronov D.V. Pravo i spravedlivost' $v$ tvorcheskom nasledii Sergeia Andreevicha Muromtseva. Reforma ili revoliutsiia. [Law and justice in the creative heritage of Sergei Andreevich Muromtsev. Reform or revolution]. Izvestiya Vysshikh Uchebnykh Zavedenii [Bulletin of Higher Education Institutions]. The Volga Region. The Humanities, 2012, no. 3, pp. 9-13. (In Russian)

4. Aronov D.V. "Proekt konstitutsii Rossiiskoi imperii s razdelami: gosudarstv[ennoe] ustroistvo, prava grazhdan, narodnoe prosveshchenie" - iz politiko-pravovogo naslediia Aleksandra Ivanovicha Guchkova ['Draft Constitution of the Russian Empire with sections: The state system, the rights of citizens, public education' - from the political and legal heritage of Alexander Ivanovich Guchkov]. History of State and Law, 2014, no. 24, pp. 49-53. (In Russian)

5. Aronov D.V. Reforma mestnogo samoupravleniia v liberal'nykh proektakh Osnovnogo zakona Rossii nachala XX veka: opyt sravnitel'nogo izucheniia [Reform of local self-government in liberal projects of the Basic Law of Russia at the beginning of the $20^{\text {th }}$ century: The experience of comparative study]. History of State and Law, 2014, no. 12, pp. 41-46. (In Russian)

6. Aronov D.V. Status monarkha v liberal'nykh proektakh Osnovnogo zakona Rossii nachala $\mathrm{XX}$ veka [Status of the monarch in the liberal projects of the Basic Law of Russia at the beginning of the $20^{\text {th }}$ century]. History of State and Law, 2013, no. 3, pp. 14-17. (In Russian)

7. Aronov D.V., Kosheleva S.V. Tipologiia gosudarstvennoi vlasti v Rossii v fevrale oktiabre 1917 g. [Typology of state power in Russia in February-October 1917]. History of State and Law, 2017, no. 19, pp. 13-17. (In Russian)

8. Aronov D.V., Sheparneva A.I., Leonova I.A., Kosheleva S.V. Proekt Osnovnogo zakona Rossiiskoi imperii Khar'kovskogo iuridicheskogo obshchestva - mesto i rol' v liberal'nom konstitutsionnom zakonotvorchestve nachala XX veka [Draft Basic Law of the Russian Empire by Kharkov Law Society - a place and role in the liberal constitutional lawmaking of the early $20^{\text {th }}$ century]. History of State and Law, 2017, no. 1, pp. 60-64. (In Russian)

9. Bobrova G.S. Stanovlenie rossiiskogo konstitutsionalizma [The Formation of Russian Constitutionalism. PhD Dis.]. Moscow, 2017. 178 p. (In Russian)

10. Butler W. Russian Law. London; Oxford, 2009. 986 p. 
11. Glushkova S.I. Problema pravovogo ideala v russkom liberalizme [The Problem of the Legal Ideal in Russian Liberalism.] Ekaterinburg: Publishing House of Humanitarian University, 2001. 466 p. (In Russian)

12. Kornev V.N. Liberal'naia kontseptsiia gosudarstva i prava v Rossii nachala KhKh veka (1905-1917 gody) [The Liberal Concept of State and Law in Russia at the Beginning of the $20^{\text {th }}$ Century (1905-1917)]. Belgorod: Publishing House of Belgorod State University, 2001. 160 p. (In Russian)

13. Late Imperial Russia: Problems and Prospects. New York, 2005. 224 p.

14. Levchuk S.V. Konstitutsionnye proekty Vremennogo pravitel'stva Rossii v mezhrevoliutsionnyi period 1917 goda [Constitutional projects of the Provisional Government of Russia in the inter-revolutionary period of 1917]. Law and Life, 1996, no. 10, pp. 155-156. (In Russian)

15. Liberal'noe dvizhenie v Rossii. 1902-1905 gg. [Liberal movement in Russia. 1902-1905] Moscow: ROSSPEN, 2001. 648 p. (In Russian)

16. Mamitova N.V. Liberal'nye kontseptsii konstitutsionnogo gosudarstva v Rossii (konets XIX $-X X$ vekov) [Liberal Concepts of the Constitutional State in Russia (end of $19^{\text {th }}-20^{\text {th }}$ centuries)]. Moscow: MGUK, 2001. 128 pp. (In Russian)

17. Medushevskii A.N. Dialog so vremenem: rossiiskie konstitutsionalisty kontsa XIX nachala $X X v v$. [Dialogue with Time: Russian Constitutionalists of the Late $19^{\text {th }}$ and Early $20^{\text {th }}$ centuries]. Moscow: New chronograph, 2010. 488 p. (In Russian)

18. Modeli obshchestvennogo pereustroistva Rossii. XX vek [Models of Public Restructuring in Russia. The 20 ${ }^{\text {th }}$ Century]. Resp. Ed. V.V. Shelokhaev. Moscow: ROSSPEN, 2004. 608 p. (In Russian)

19. Power and Legitimacy - Challengers from Russia. London; New York, 2012. 256 p.

20. Repnikov A.V. Konservativnye kontseptsii pereustroistva Rossii [Conservative Concepts of the Reorganization of Russia]. Moscow: Academia, 2007. 520 p. (In Russian)

21. Shelokhaev V.V. Liberal'naia model' pereustroistva Rossii [The Liberal Model of the Reorganization of Russia]. Moscow: ROSSPEN, 1996. 280 pp. (In Russian)

22. S"ezdy i konferentsii Konstitutsionno-demokraticheskoi partii. 1905-1920 gg [Congresses and conferences of the Constitutional Democratic Party. 1905-1920]. Moscow: ROSSPEN, 2000, vol. 3, book. 1.831 p. (In Russian)

23. The Rise and Fall of Soviet Union. A Selected Bibliography of Sources in English. London, 1992. $448 \mathrm{p}$.

24. The Russian Provisional Government. 1917. Documents. Selected and edited by R.P. Browder and A.F. Kerensky. Stanford Univ. Press. Stanford, California, 1961. Vol. I-III.

25. The Russian Revolution and the Soviet State. 1917-1921. Documents. Selected and Edited by Mc Cauley. London, 1975. 317 p.

26. Zhukov V.N. Russkaia filosofiia prava: Estestvenno-pravovaia shkola pervoi poloviny XXveka [Russian Philosophy of Law: The Natural Law School of the First Half of the $20^{\text {th }}$ Century]. Moscow: Russian Humanist Society, 2001. 237 p. (In Russian) 